\title{
First salt making in Europe: an overview from Neolithic times
}

\author{
Olivier Weller \\ CNRS, UMR 8215 Trajectoires, Maison de l'Archéologie et de l'Ethnologie, Université Paris 1 Panthéon-Sorbonne, FR \\ olivier.weller@mae.cnrs.fr
}

\begin{abstract}
This paper deals with the origin of salt production and discusses different approaches ranging from technology, ethnoarchaeology and paleoenvironmental studies to chemical analyses. Starting from the current research on the Neolithic exploitation of salt in Europe, we examine the types and nature of the salt resources (sea water, salt springs, soil or rock), the diversity of archaeological evidence of forms of salt working. We also scrutinize the types of production for these early forms of salt exploitation, with or without the use of crudely fired clay vessels (briquetage). Finally, we contextualise the socio-economic dimensions and highlight both the diversity of salt products and their characteristics, which go well beyond dietary roles.
\end{abstract}

IZVLEČEK - V članku predstavljamo izvor pridobivanja soli in razpravljamo o različnih pristopih, ki sežejo od tehnologije, etnoarheologije, paleookoljskih študij in vse do kemijskih analiz. Razpravo začnemo s sodobnimi raziskavami o izkoriščanju soli v neolitiku v Evropi, preiščemo različne tipe in naravo izvorov soli (morska voda, slani izviri, tla ali kamnine) ter raznolikost arheoloških podatkov o pridobivanju in predelavi soli. Temeljito smo preiskali tipe produkcije za prvotne oblike pridobivanja soli, kjer je za nekatere značilna tudi uporaba grobih keramičnih posod ('briquetage'). Na koncu poskušamo kontekstualizirati družbeno-ekonomske vplive predelave soli in osvetliti izdelke iz soli, tako glede na njihovo raznolikost kot tudi glede na njihove značilnosti, saj imajo več kot le prehrambno vlogo.

KEY WORDS - salt production; Neolithic; Europe; archaeological evidence

\section{Introduction}

If, today, salt is an ordinary good, a practically inexhaustible substance, both alimentary and industrial, this was not the case in countless pre-industrial societies. It is at least since the Neolithic that European agropastoral societies have sought to extract it from its natural sources, or more precisely since the $6^{\text {th }}$ millennium BC. Nowadays, we probably associate the exploitation of salt with coastal salt marshes; yet a great share of production still comes from artificially heating brine or simply from the extraction of rock salt. While regular table salt, or sodium chloride, seems an inexhaustible natural commodity, neither its geographic distribution, nor its physical forms are uniform. Salt is found in either solid (rocks, outcrops, earths, sands, plants) or liquid form (sea or spring waters, bodily fluids). Furthermore, it is pre- sent in highly variable concentrations, ranging from a few grams in blood or urine, to almost $200 \mathrm{~g} / \mathrm{l}$ in certain salt springs or enclosed seas, attaining an average of $30 \mathrm{~g} / \mathrm{l}$ in oceanic waters. It crystallises at concentrations of around $330 \mathrm{~g} / \mathrm{l}$ of water.

Faced with this disparity in concentration and distribution, humanity has resorted to a wide assortment of extraction techniques. Nonetheless, apart from the exploitation of rock salt, extraction most often consists, in some cases after the lixiviation of a salty solid, of processing a liquid by subjecting it to a natural (solar salt) or artificial (ignigenous salt) evaporation process, until crystallisation is achieved (Fig. 1). The grained salt obtained can be then used as such or packaged as hard blocks in standardised shapes 
and weights (Gouletquer, Weller 2015), which can be preserved in this form or readily transported and traded over long distances.

The diversity of methods observed around the world seem intimately linked to environmental contexts and types of saliferous resources exploited; it also mirrors the quality of the product being sought (type of salts, salted ashes, grained salt, or salt blocks), and to the specificities of demand and of social context (Gouletquer et al. 1994).

\section{The issue of origins}

Although archaeologists and scholars have examined ancient mines or the abundant debris of fired clay (briquetage) produced since the Iron Age up to the $18^{\text {th }}$ century, research on the origins of salt exploitation harking back to the Early Neolithic has not yet even commenced. At first glance, one can easily understand why, in the absence of the very object of research, the issue of salt exploitation in the prehistoric period has remained poorly addressed. However, while nothing has remained of the product, the archaeological realities around salt exploitation have been ascertained in the field with the help of various types of evidence, which inform us non-vicariously of the techniques employed (catchments, pottery or charcoal accumulations), or more indirectly of their impact on the environment, territorial organisation, or circulation of goods.

Besides the discussion on the archaeological remains themselves, it is the general question of the function of salt which emerges. Indeed, how can we explain the appearance of this new exploitation of the natural environment? What were the reasons for which simple occasional collecting from a furrowed rock or from the edge of a salt spring were no longer sufficient for these early Neolithic salt-producing communities, which now set about separating salt from its natural support (water, rocks, soils or plants) and, as such, to produce a hard, transportable and shaped product? While many researchers have turned to biology and psychology to answer this question, others have looked for answers in ethnographic investiga- tions. Indeed, does the biological hypotheses, according to which salt was an essential nutritional element within the new Neolithic alimentary diet, suffices to explain its exploitation?

In order to confront nutritionists' hypotheses with the archaeological realities, and to characterise the production of salt and its socio-economic implications, it is necessary to develop a multidisciplinary approach and to multiply the ethnographic, historical, environmental, archaeometric, and experimental observations. Therefore, it was necessary to make use of several methods that, in conjunction, can shed light on the archaeological realities. By illustrating our goal with various case studies from across Europe, we seek to tackle the issue of salt exploitation from the methodological standpoints of the different approaches that may be invoked, and of the elements that so far seem diagnostic. Also, we will see how the study of known or newly brought to light vestiges and of relative archaeological contexts can allow a reconsideration of the diversity of functions performed by salt, in which alimentation is not necessary the cornerstone.

\section{Archaeological evidence}

Whether or not one adheres to the biological argument, pre-historians have only recently considered other possible functions of salt in these early agricultural societies. Yet we know that the scarcity of exploitable natural resources meant that at specific times in history, salt played an important economic and social role, prior to being used for multiple dayto-day applications of which we are now fully aware (preservative, adjuvant for the dairy industry, tanning agent, metallurgy of precious metals, dye-fix-

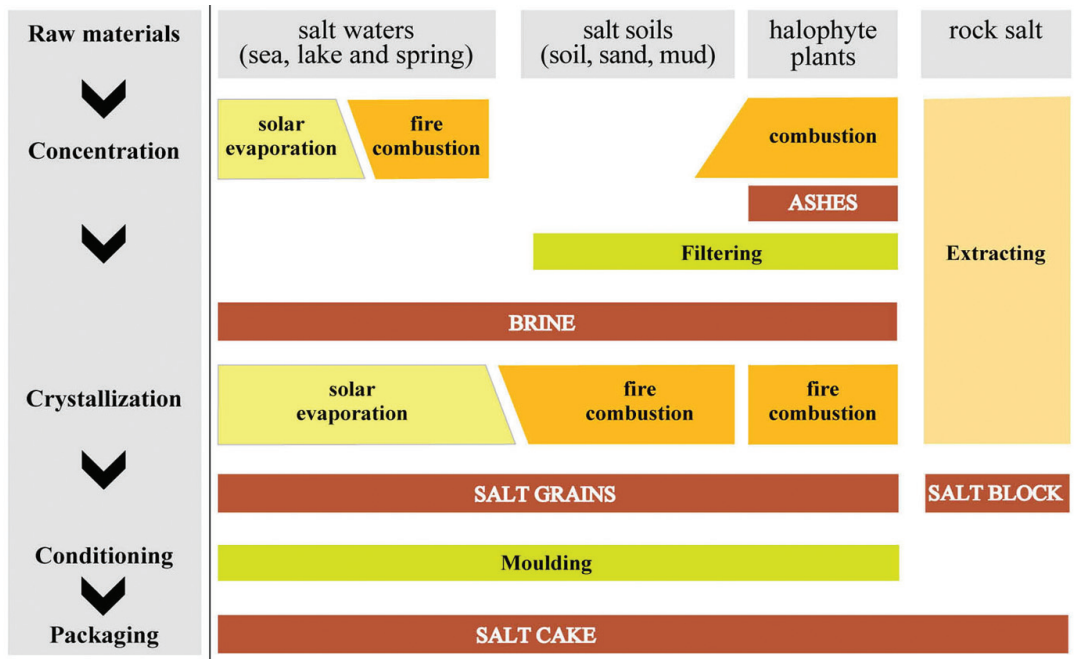

Fig. 1. General principles of salt production (drawing 0 . Weller). 
ing, medication ...). Moreover, it has long been held that - just as with the production techniques of the Iron Age - salt exploitation was dependent only on the identification of vestiges or fired-clay structures collectively known as briquetage. Today, the variety of forms of exploitation recognised by both ethnography and archaeology (Alexianu et al. 2011; Brigand, Weller 2015; Cassen et al. 2008; Cassen, Weller 2013; Fíguls, Weller 2007; Harding 2013; Hocquet et al. 2001; Monah et al. 2007; Nikolov, Bacvarov 2012; Pétrequin et al. 2001; Weller 2002; Weller et al. 2008) allows us to return to the issue of the function of certain material remains, and to advance new hypotheses on the place of this irreplaceable substance also in the domestic, technical and socio-economic spheres.

The directly observable material remains of prehistoric salt production can sometimes be found in the form of wooden catchments or fittings, but most often it consists of accumulations of fired clay (or briquetage) comprising debris from ancient heating installations and fragments of salt pans, accumulations of charcoal and ashes, unearthed structures, or, in the case of rock salt exploitation, of stone tools. We should note that no such remains are known at present from salt marshes, and that such inventions should be dated to the Roman period (not the Middle Ages), as shown by the excavations from Vigo in Portugal (Castro Carrera 2008).

\section{Spring catchment and fittings}

The construction of catchment systems and retention basins around salt springs is difficult to ascertain in cases of heavy erosion or rapid sedimentation. However, French examples such as the spring at Moriez in the Alps, where researchers unearthed the frame of an ancient lathwork dated to around 5600 BC (Morin et al. 2008), or that from Grozon in the Jura, where salt workers had erected a genuine horseshoe-shaped bulwark to protect the spring (Pétrequin et al. 2001), suggest that the search for such structures should continue.

Many wooden structures have been observed during rehabilitation works or in capturing salt springs, but their dating is often problematic (missing elements, brief remarks at the moment of discovery etc.). The most eloquent are the 19 oak trunks at Fontaines Salées in Saint-Père-sous-Vézelay (Yonne, France)

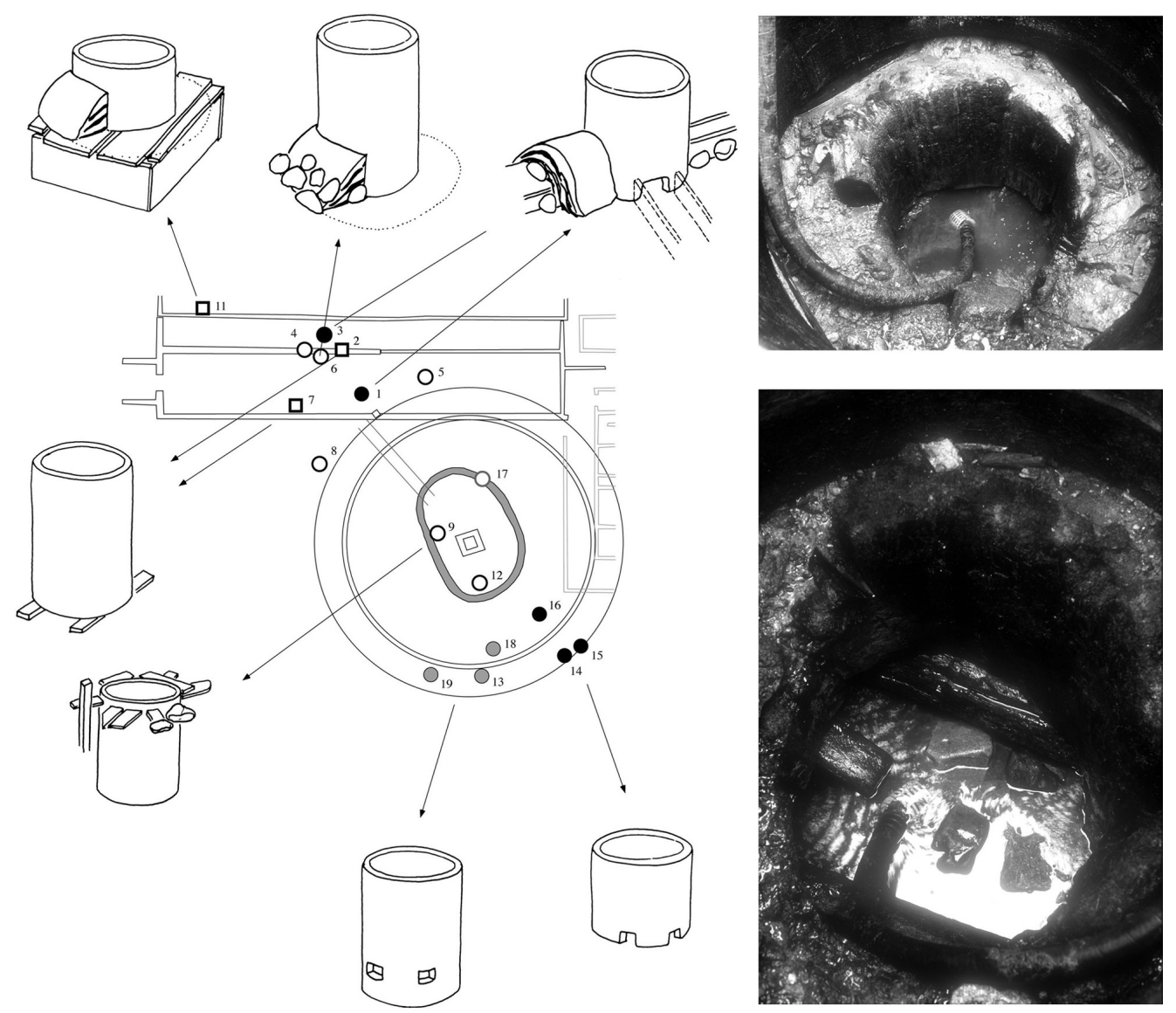

Fig. 2. Neolithic wooden wells from FontainesSalées, Saint-Père-sous-Vézelay, Yonne, France (drawing P. Pétrequin and photos 0 . Weller) 

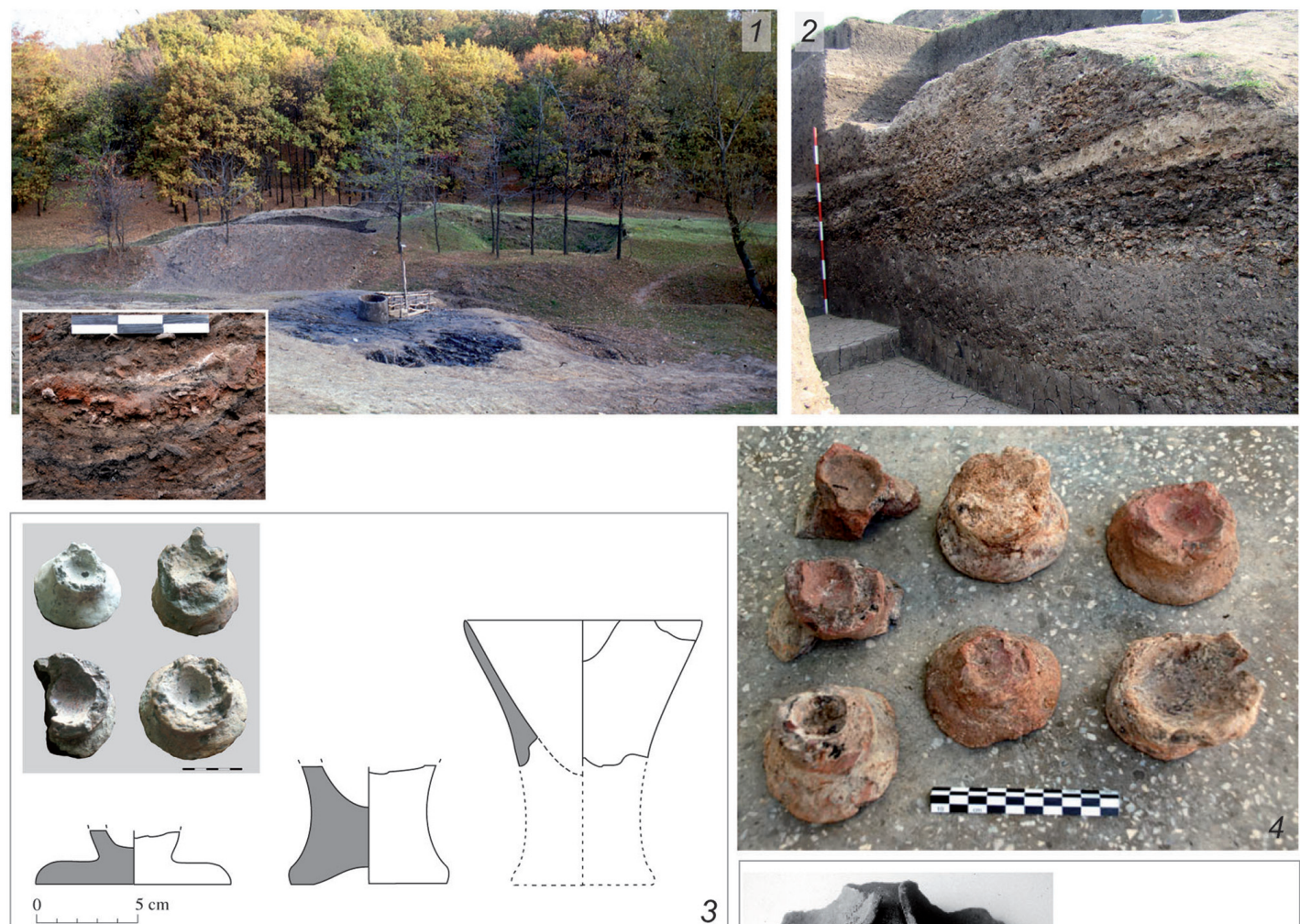

0

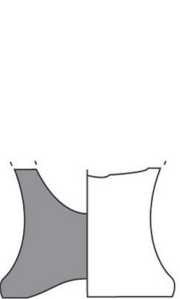

3
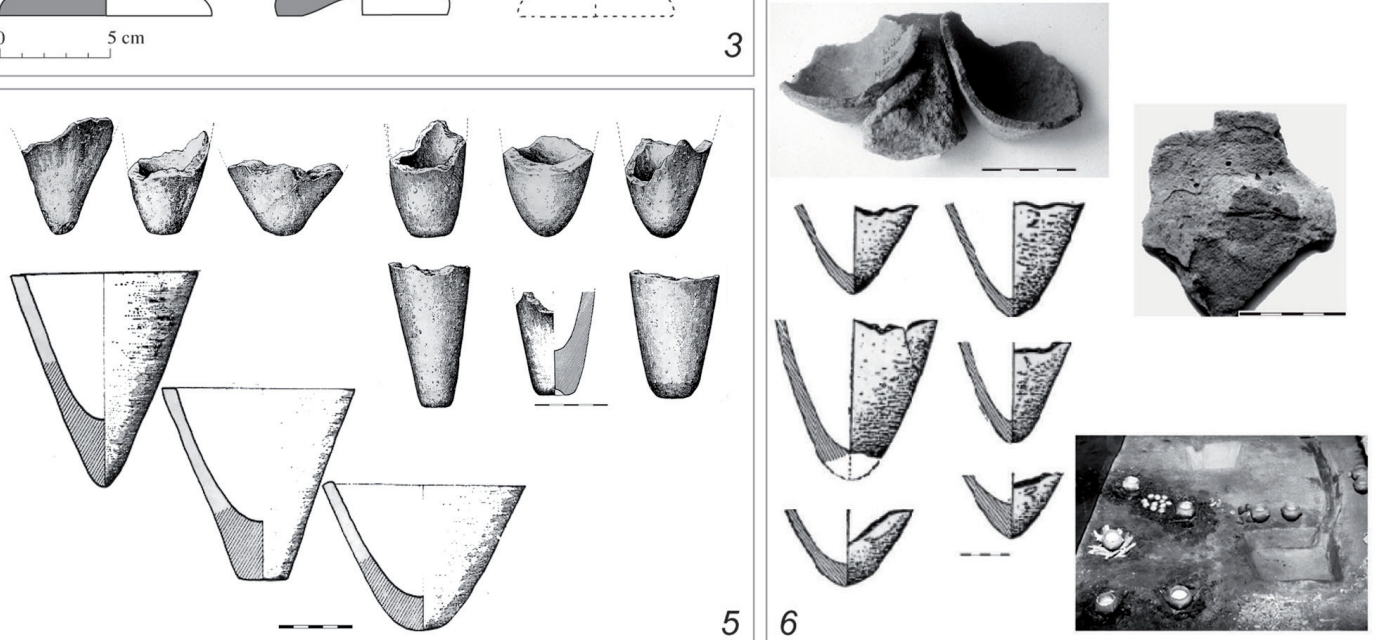

Fig. 3. Evidences of salt exploitation in Central and Eastern Europe between the $5^{\text {th }}$ and $4^{\text {th }}$ millenniums BC: 1 accumulation of firewood places from the Early Neolithic at Lunca-Poiana Slatinei (Romania); 2 succession of archaeological layers extremely rich in pottery from the Precucuteni and Cucuteni cultures at Tolici-Hălăbutoaia (Romania); 3, 4 briquetage from the Cucuteni culture (Lunca and Tolici, Romania); 5 briquetage from the Vinča culture (Tuzla, Bosnia and Herzegovina); 6 briquetage with an element of a stove, corroded ceramic and model from Barycz VII (Poland) (photos and drawings 0 . Weller except drawings 5 (Benac 1978) and 6 (Jodłowski 1977).

(Fig. 2), formerly attributed to the onset of the Iron Age, but nowadays re-examined and dated dendrochronologically to the $23^{\text {rd }}$ century $\mathrm{BC}$, that is to say contemporary with the Bell Beaker culture (Bernard et al. 2008).

\section{Fired-clay vessels (or briquetage)}

The exploitation of salt during the Neolithic and Chalcolithic seems in some cases to have been particularly dynamic on account of the considerable quan- tities of fragments of ceramic moulds accumulated around certain salt springs, sometimes associated with combustion structures or residues (Weller 2002a). This is the case with salt springs in Little Poland, Bosnia-Herzegovina, Romanian Moldavia (Fig. 3.2-6), or, more recently, Bulgaria (Fig. 4), all exploited by means of fired-clay moulds during the middle of the $5^{\text {th }}$ millennium BC. Around $3000 \mathrm{BC}$, on the Atlantic coast, the enclosures around the Poitevin Marsh in France produced a very large quan- 

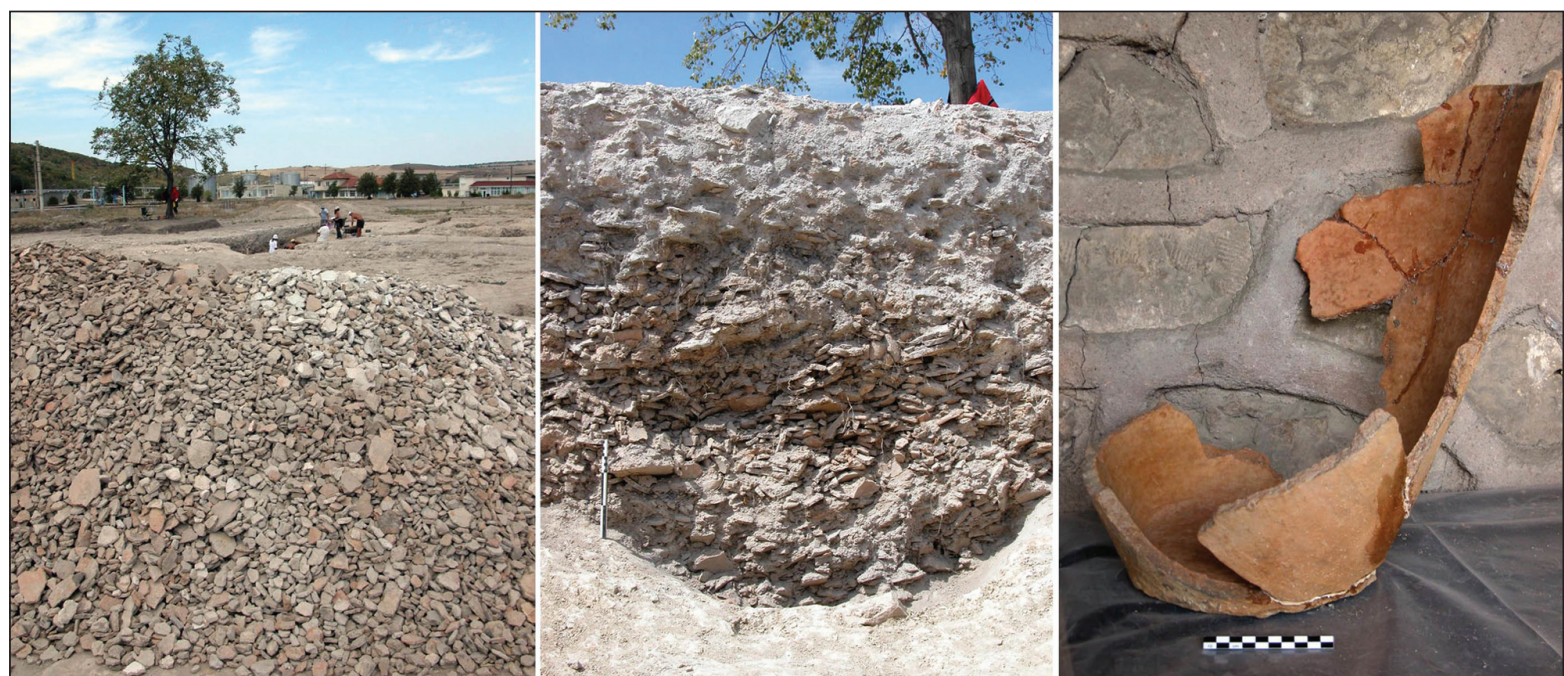

Fig. 4. Chalcolithic salt moulds accumulation in Solnitsata, Provadija, Bulgaria (photos O. Weller).

tity of briquetage (Ard, Weller 2012), while in Germany the salt springs from Halle furnish the first fired-clay moulds.

This specific ceramic ware, in all instances abundant and clearly distinct from domestic pottery, display the same general characteristics: clay of local provenance, numerous inclusions, sometimes accounting for a quite large share of the paste; abundant tempering (sand, plant matter, grog, etc.); open shape; crude fashioning from a clay lump or from coils, finger or plant imprints, traces of wickerwork on the base; the edges and outer walls are unfinished, but the interior is neatly smoothed. Fragmentation is nonetheless significant, due to deliberate breaking to extract salt cakes. Across different producing sites, the bases of the vessels, sometimes complete, constitute in some cases the majority of the ceramic harvest; the edges adhere to the salt cakes and can serve to trace distribution paths.

These salt moulds thus serve both as casts and crystallisers. If for some their function still remains at the level of hypothesis, such as the flat-based pots in the Carnac Mounds or the Cycladic 'frying pans' (Cassen et al. 2012), we were able to confirm this for others through a series of chemical analyses based on an assay of chlorine (Weller 2002a; Weller, Ard forthcoming). Basically, the levels of chlorine in the salt moulds are 2 to 20 times higher than in domestic contexts. These values are greater still, as the rainwater infiltration is lower.

The use of ceramic moulds of practically identical shape and volume by each cultural group attests to the commitment to producing and packaging salt ac- cording to a predefined shape, in compact form and easy to transport. The production was not aimed at simply producing salt, but salt cakes of a standardised quality, size and weight. The salt cake thus becomes a social object, an identity marker of the producers. In this form, it will circulate conveniently, be divided without losing its use value, and be stored for many years.

It was in Central and Eastern Europe, in the Chalcolithic, specifically the middle of the $5^{\text {th }}$ millennium $\mathrm{BC}$, that the crystallisation and moulding of salt in vessels of fired clay developed (Weller 2012). The appearance of these chemical techniques alongside the first copper objects, similarly cast, reveals a new conception of the properties of matter, of making visible and malleable a substance that is initially invisible. Nonetheless, with the exception of a fragment of a furnace discovered in Little Poland, there are no known genuine combustion structures from this era, and Western Europe had to await the Bronze Age to produce such structures, and then the Iron Age for salt-works in the true meaning of the word.

\section{Charcoal accumulations}

For a long time, it was thought that in the absence of fired clay (ceramics, supports, accessories and fragments of furnaces or kilns), we could not demonstrate the exploitation of salt. However, other techniques of salt production do not necessitate the use of fired clay or kilns. The ethnographic studies conducted in New Guinea (Weller et al. 1996; Pétrequin et al. 2001) and the archaeological work in eastern France (Franche-Comté) revealed methods of exploitation that do not require the use of fired clay or furnaces, but other techniques involving the 
use of vegetal matter as raw material and which produce considerable quantities of charcoal and ash (Pétrequin, Weller 2008). Finding ancient accumulations of charcoal around salt springs or littoral marshes thus becomes a new challenge for the research on ancient forms of salt production.

To have an image, if not for the production of salt, at least for the approximate volume of charcoal and waste on the river basin, the case of Salins-les-Bains (Jura) is exemplary: the charcoal from the production of salt during the $18^{\text {th }}$ century is visible in the alluvial deposits to a distance of up to $10 \mathrm{~km}$ downstream from the salt-works; with respect to the charcoal produced during the Neolithic dated to around $3000 \mathrm{BC}$, it is still present in large quantities in the clogged meanders some $7 \mathrm{~km}$ downstream from the salt exploitation area.

Over thousands of years, a massive quantity of fuel was consumed in order to produce salt. For instance, the longitudinal section of the Grozon basin (Jura) across $400 \mathrm{~m}$ has revealed carbonaceous layers over $7 \mathrm{~m}$ thick, dated to between the early $4^{\text {th }}$ millennium $\mathrm{BC}$ and the Roman period (Fig. 5). The end of the exploitation during the Gallo-Roman era is marked by the entrenchment of the Romans around the salt springs (or the coastal marshes, respectively) presumably to put a halt to Gallic exploitation and to sell their own Mediterranean salt.

As for the paleoenvironmental approaches, palynologic and anthracologic analyses represent the most promising research directions. By studying the sedimentary sequences spread across the depressions near or immediately downstream of the salt exploitation points, it is possible to trace the management of the fuel and the history of deforesting (Dufraisse, Gauthier 2002). It is particularly possible to differentiate deforesting for agricultural purposes (where the pollen of certain crops are well represented) and deforestation associated only with the exploitation of salt, in the case of a spring located at that moment outside the area of permanent settlement and cultivated land. But the accuracy of the pollen charts is directly affected by the quality of the preserved pollen and the recording of the chronological sequences; this means that marshes and depressions with wet environments should be the prime targets of core boring and sample collecting.

With respect to exploitation techniques, in the light of our own ethnographic study in Indonesian New Guinea, following a re-examination of the ancient sources (mainly Pliny, Tacitus and Varro) and a series of life-size experiments (Pétrequin, Weller 2008), the extraction of salt without recipients is today better known for the Middle Neolithic of Eastern France, and similarly proved for the Early Neolithic of Romania (Fig. 3.1) (Weller, Dumitroaia 2005; Weller et al. 2008). They involve the direct spillage of saline water over an incandescent pyre covered by a vegetal blanket meant to slow down the falling water. The saline water is concentrated along the running path, just as in the techniques used in the gradual-evaporation salt factories of $16^{\text {th }}-19^{\text {th }}$ century Germany and eastern France; in contact with the incandescent embers, the salt crystallises instantly. The small salt crystals are subsequently recovered from the ash and cinders, and packaged in a form that still eludes us.

\section{The exploitation structures and buildings}

Always built in the immediate proximity and view of the salt springs, according to the ethnographic data, the buildings and structures for exploitation are still largely unknown. Examples include the saltworks from Little Poland (pits, ditches and foundation post holes at the site of Barycz VII), the pits at Provadija in Bulgaria (Nikolov 2008), or the Neolithic pits at Sandun (Loire-Atlantique, France), rightly interpreted (Cassen et al. 2008) as pits for filtering salty sand and collecting brine, just like the pre-Hispanic vestiges in Mexico (Fig. 6) (Liot 2000), or the Gallic sites in northern France (Edeine 1970). In the case of Sandun, therefore, the real function of the site which has thus far been considered a marshedge settlement that must be reconsidered. Serge Cassen also invites us to readdress the function of the different structures unearthed in several sites presumed to be settlements in France and Italy, or the so-called Cultura de los silos de Baja Andalucía, which he proposes should be reinterpreted as places for producing salt primarily by washing very fine sand: intriguing hypotheses which must be tested in the field.

\section{The first Neolithic mining tools}

The only salt mountain in Western Europe is found in Cardona in Catalonia, about $80 \mathrm{~km}$ northwest of Barcelona. This varicoloured Muntanya de Sal reaches more than $140 \mathrm{~m}$ in height. Despite the abundant research on Neolithic burials in the region in the early $20^{\text {th }}$ century and the discovery of stone tools around the salt outcrops, the hypothesis of Neolithic extraction was hastily abandoned after the 1930s. Thereafter, this region in the foothills of the Pyrenees remained outside the large-scale research 
endeavours and archaeological campaign concentrated along the Catalan shoreline.

However, starting from a series of chance finds collected since the start of the last century by prospectors, farmers or workers from this salt mine, we were able to study several hundred stone tools comprising hammers, reused axes, pestles, and bush- hammers (Weller 2002b; Fíguls et al. 2013). Their technological analysis showed that Neolithic workers used mining tools associated with the exploitation of rock salt in the form of an open quarry (Fig. 7). The salt blocks extracted from the outcrops were transported to the surrounding settlements to be transformed by mortar, and probably regularised, into blocks of salt of standard shapes and weights.

UPSTREAM

DOWNSTREAM
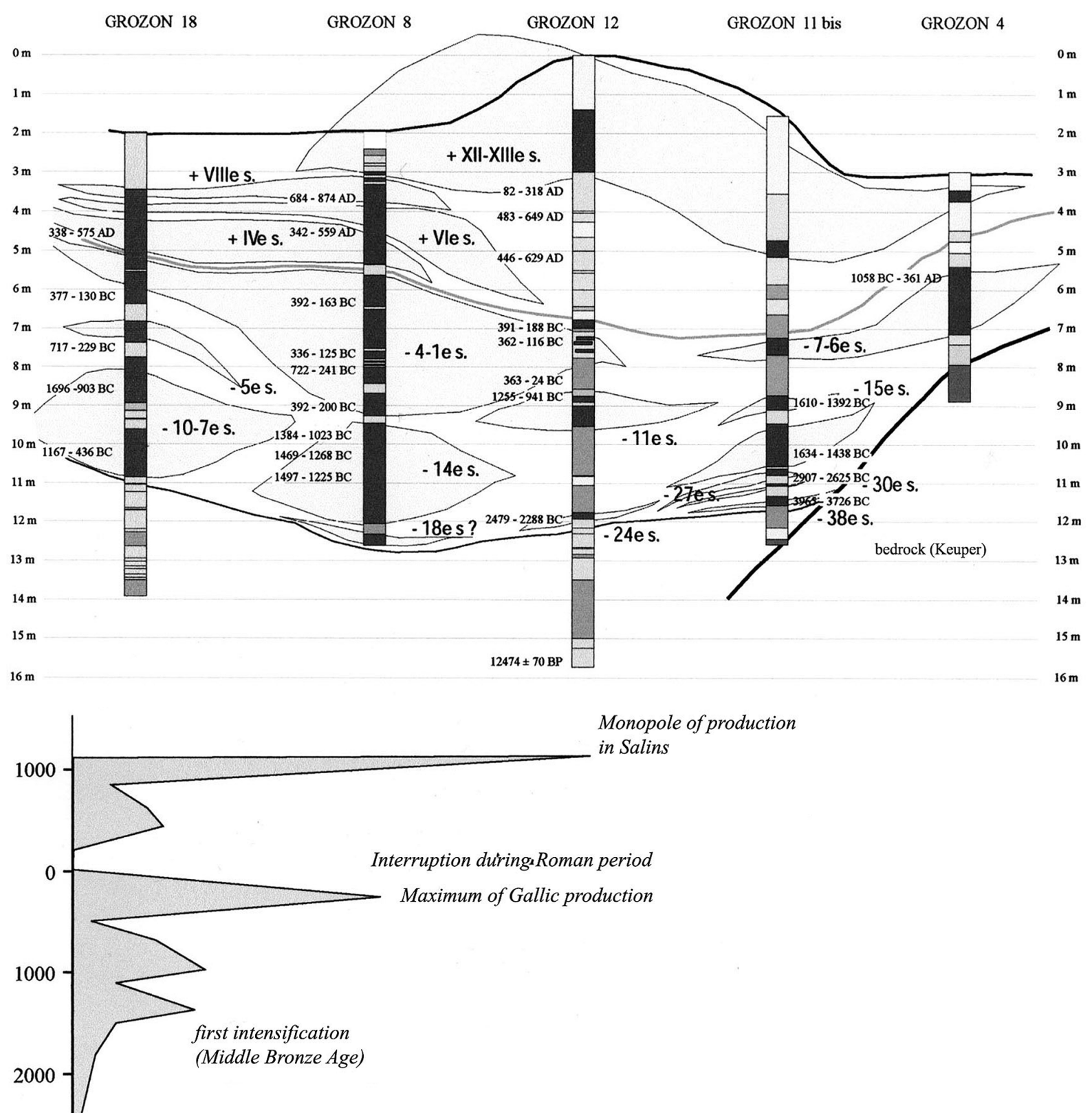

Fig. 5. Salt exploitation in Grozon (Jura, France): Longitudinal stratigraphic cut of the Grozon basin (400m) based on drill cores and dated by radiocarbon. The depression was created after the underlying salt-rock was dissolved (top). Schematic chronological evolution of the charcoal sediments volume related to salt exploitation (bottom) (drawings P. Pétrequin). 


\section{The socio-economic implications}

Discerning the economic and social aftermath of the production of, and trade in, salt consists firstly of identifying, in the vicinity of the salt springs, the specific concentrations of settlements, and therefore of the population (Brigand, Weller 2013; 2015), or of valuables in the form of deposits (Harding 2013), imported goods or spectacular graves. But this is where interpretation is most difficult, particularly since the ethnographic model of chieftain societies specific to the highlands of Indonesian New Guinea is only one among many other examples of ways in which a society can be structured. Here, there are no buried treasures, no graves of momentarily prominent individuals, simply because the forms of power are transmitted equally through the exchange and redistribution of wealth. Other ethnoarchaeological models should be tested before attempting to characterise social behaviours founded on social inequality, such as those which around the middle of the $5^{\text {th }}$ millennium $\mathrm{BC}$ engendered the monumental tombs from the Gulf of Morbihan (France), a particularly suitable area for the exploitation of salt (Gouletquer, Weller 2002; Cassen et al. 2012).

On the question of the type of organisation and a conceivable specialisation of the crystallised salt industry by Neolithic groups in northern $\mathrm{Ca}$ talonia (Weller, Fíguls 2013), the great portion of tools reused and manufactured from fractured polished axes, their distribution over an area of more than $20 \mathrm{~km}$ around the salt deposit, their low degree of technical development, and above all the plausible absence of any major fortified control settlement, all suggest open exploitation, not one reserved to a single small group of local specialists. However, the relative richness of the graves of this group in goods imported from the coast (va-

riscite pearls from Gavà, the largest ever known, bracelets and pearls from shells, yellow flint imported from Haute-Provence) suggests salt had an elevated position within a wider regional exchange network.

We may also mention the close spatial correlation observed in Germany between salt springs and the distribution of greenstone long alpine axes, which demonstrate that salt could have played a key role in the acquisition of these rich and ceremonial objects (Weller 2002a). Nonetheless, the age of the exploitation of these highly saline springs remains to be established; only fired-clay remains used since the late Neolithic have been subject of studies.

In any case, throughout Western Europe during the $5^{\text {th }}$ millennium BC, certain saliferous resources, whe-
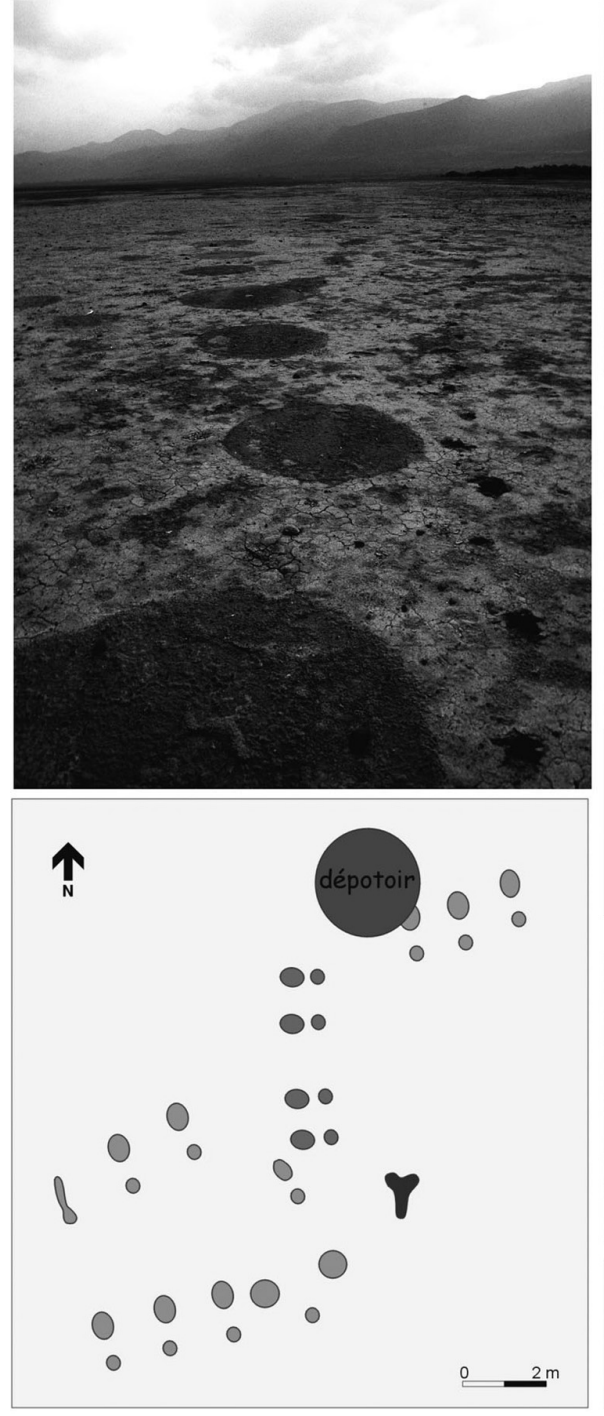

Fig. 6. Pits for leaching salty soils, with watertight facing, simple, double or multiple from the Pre-Hispanic salt production centre on the edge of the Sayula basin (Jalisco, Mexico) (photos O. Weller (left) and C. Liot (right), drawings C. Liot). 


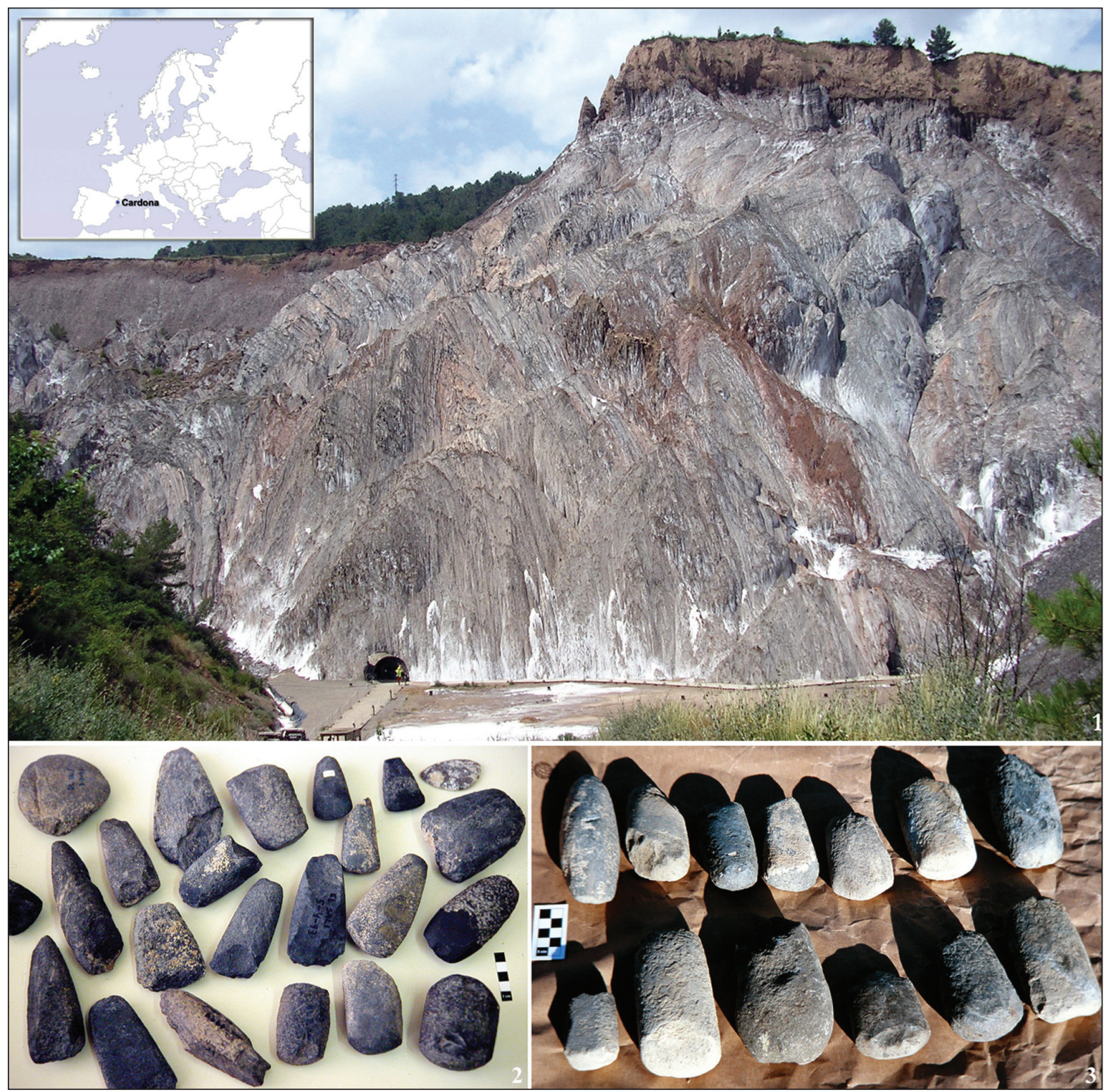

Fig. 7. Salt outcrops from the Vall Salina in Cardona (Catalonia, Spain) and mining tools for extraction (2) and shaped (3) the salt blocks (photos O. Weller).

ther inner-continental or coastal, appear to have acted as hubs capable of 'drawing' into their networks these large polished alpine axes with attached social value, while in Carpathian-Balkan Europe, the first copper and gold objects probably integrated such networks. It is thus necessary to turn decisively towards a political geography of salt.

\section{Conclusions}

Depending on the nature of the salt exploitation and the modes of occupation of territories rich in saliferous resources, this production was occasional, regular or heavily invested, and also modulated by the different uses and functions of the product. These different organisations responded to the different uses of salt, varying according to the social context, and salt most definitely did not have the same value irrespective of time and place. From this point of view, the circulation paths, the exchange pathways, and the social context were determining factors.

If the prevailing hypotheses on the function of salt during the Neolithic are primarily biological, in line with the ubiquitous adage 'salt is essential to humans', the substance further acquired other uses, more recently established: preserving foods, making dairy products, fixing dyes, hide processing, etc. However, the existence of idiosyncratic configurations of spatial organisation around saliferous re- 


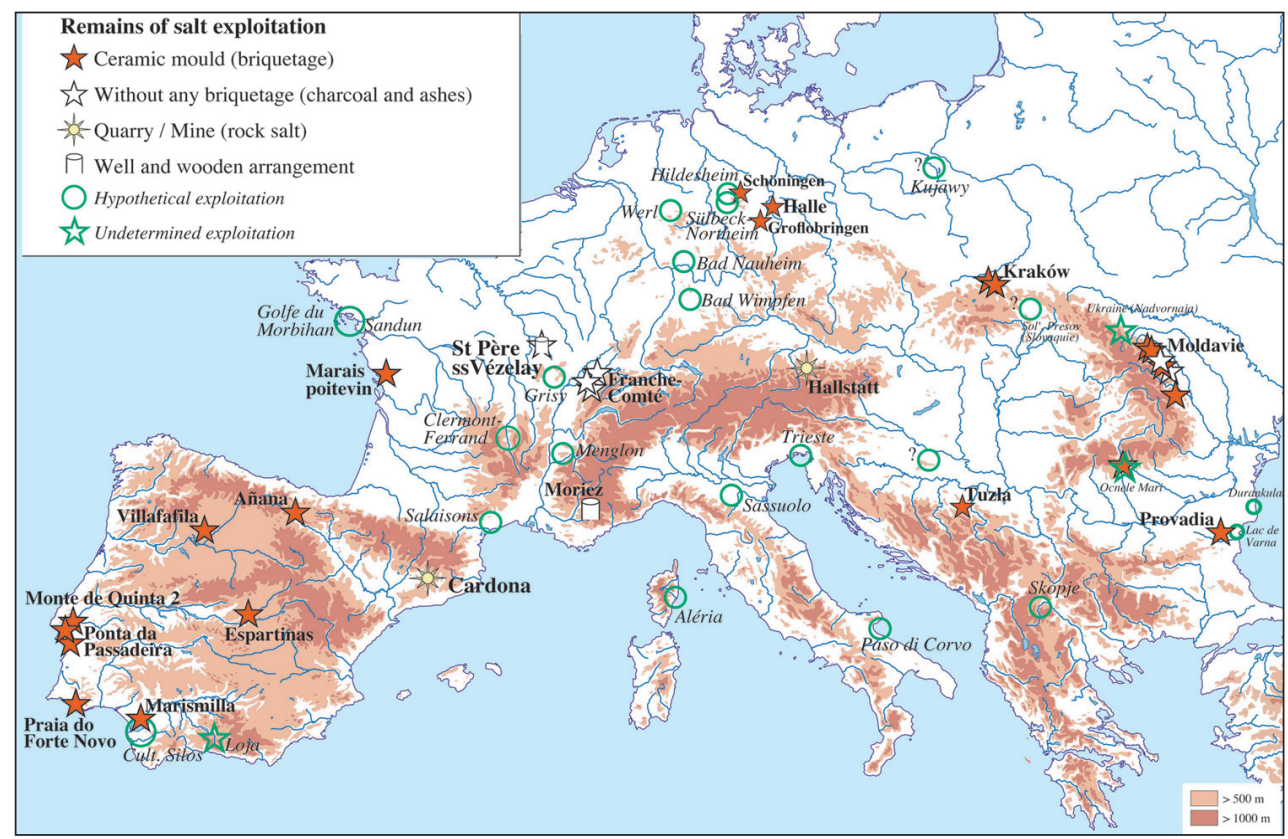

Fig. 8. An European assessment for the Neolithic and Chalcolithic periods (6000-2300 BC): the various archaeological evidences for salt production (drawing 0 . Weller).

sources opens the door to other hypotheses besides the strictly utilitarian or functionalist explanations so far sanctioned by pre-historians. The diversity of functions played by salt in contemporary traditional societies shows that its status cannot be reduced to that of a simple household and nutritional chemical substance, especially because during the $5^{\text {th }}$ millennium $\mathrm{BC}$ it was the focus of a massive technical and economic investment, as evidenced by its being made into cakes in Central and South-eastern Europe.

The appearance of the first Neolithic moulds means that salt in the form of salt cakes became a standardised item, dividable, transportable and storable, or, briefly said, a socialised good, an identity marker, capable of enabling long-distance exchange networks. Besides its role in human and animal alimentation, salt could have played, in certain contexts, the role of an exchange good as a form of durable storage of a substance that is unique in terms of its qualities, of the areas suitable for its exploitation, and of its technical and economic charge.

We also notice that this intensification of exploitations of moulded salt in Central and South-eastern Europe coincides with periods of expansion of major groups such as the Lengyel (Poland), Vinča (Serbia, Croatia, Bosnia), Cucuteni (Romania), or Hamangia (Bulgaria) cultures. Salt cakes could have been one of the means by which social tensions generated by these population movements were de- fused. However, they were not necessarily used by all the expanding groups during this period of intensifying social relations, and were not routinely involved in all processes of social regulation. It was just one possible form of storing wealth, one of the ways of taking part in the exchange.

As for the present, we are moving towards a European-wide geography of techniques of salt production (Fig. 8), in which the technical investments, the economic and social status of this activity, and also the accompanying mental and social representations, can be pinpointed. It remains for us to define more precisely the forms of exploitation used in certain areas particularly suitable for extraction, for which only indirect evidence are available, but where the socio-economic contexts suggest remarkable production (the lagoon areas of Morbihan, the highly saline springs from Halle/ Salle and Bad Nauheim in Germany, the salt springs and saline lagoons of the Spanish interior $e t c$.).

This study on an eminently soluble object is just the beginning, and future research should prioritise not only the search for undiscovered traces of exploitation (salt moulds, ceramics for boiling, filtration or storage structures, wooden catchment fittings, accumulations of ashes and charcoal, extraction implements and tools ...), but should also seek to characterise the social behaviours of the groups that manipulated this substance and the historical processes engendered by them. 


\section{References}

Alexianu M., Weller 0. and Curca R. (eds.) 2011. Archaeology and Anthropology of salt. A diachronic approach. Proceedings of the International Colloquium, 1-5 October 2008, Alexandru Ioan Cuza University (Iaşi, Romania). British Archaeological Reports IS 2198. Archaeopress. Oxford.

Ard V., Weller 0. 2012. Les vases de «type Champ-Durand«: témoins d'une exploitation du sel au Néolithique récent dans le Marais poitevin. In R. Joussaume (ed.), L'enceinte néolithique de Champ-Durand à Nieul-sur-l'Autise (Vendée). Association des publications chauvinoises. Chauvigny: 309-333.

Benac A. 1978. Neke karakteristike neoliskih naselja u Bosni i Hercegovini. Materijali 14: 15-27.

Bernard V., Pétrequin P. and Weller 0. 2008. Captages en bois à la fin du Néolithique: les Fontaines Salées à SaintPère-sous-Vézelay. In O. Weller, A. Dufraisse and P. Pétrequin (eds.), Sel, eau et forêt. D'hier à aujourd'hui. Cahiers de la MSH Ledoux 12 (coll. Homme et environnement 1). Presses Universitaires de Franche-Comté. Besançon: 299-333.

Brigand R., Weller 0. 2013. Neolithic and Chalcolithic settlement pattern in central Moldavia (Romania). Documenta Praehistorica 40: 195-207.

2015. Spatial Models for Salt Archaeology. A Neolithic case study from Moldova (Romania). In R. Brigand, 0 . Weller (eds.), Archaeology of Salt. Approaching an invisible past. Sidestone. Leiden: 157-179.

(eds.) 2015. Archaeology of Salt. Approaching an invisible past. Sidestone. Leiden.

Cassen S., de Labriffe P.-A. and Menanteau L. 2008. Washing and heating on the Neolithic shores of Western Europe. An archaeological hypothesis on the production of sea salt. In O. Weller, A. Dufraisse and P. Pétrequin (eds.), Sel, eau et forêt. D'hier à aujourd'hui. Cahiers de la MSH Ledoux 12 (coll. Homme et environnement 1). Presses Universitaires de Franche-Comté. Besançon: 175-204.

Cassen S., Viguier E., Weller O., Chaigneau C., Hamon G., de Labriffe P.-A. and Martin C. 2012. Neolithic flat-based pots from the Carnac Mounds in the light of Cycladic 'frying pans'. Documenta Praehistorica 39: 309-324.

Cassen S. Weller 0. 2013. Idées et faits relatifs à la production des sels marins et terrestres en Europe, du VIe au IIIe millénaire. In J. Soares (ed.), Prehistory of Wetlands. Landscapes of salt. Setúbal Arqueológica 14. Museum of Archaeology and Ethnography of the District of Setúbal (MAEDS). Setúbal: 255-304.
Castro Carrera J. C. 2008. La saline romaine de 'O Areal', Vigo (Galice): architecture d'une installation industrielle de production de sel marin. In 0. Weller, A. Dufraisse and P. Pétrequin (eds.), Sel, eau et forêt. D'hier à aujourd'hui. Presses Universitaires de Franche-Comté. Cahiers de la MSH Ledoux 12 (coll. Homme et environnement 1). Besançon: 381-399.

Dufraisse A., Gauthier E. 2002. Exploitation des sources salées en Franche-Comté: impact sur l'espace forestier du Néolithique à la période médiévale. In 0 . Weller (ed.), Archéologie du sel. Techniques et sociétés. Internationale Archäologie. Arbeitsgemeinschaft Symposium Tagung Kongress 3. Verlag Marie Leidorf GmbH. Rahden: 243-257.

Edeine B. 1970. La technique de fabrication du sel marin dans les sauneries protohistoriques. Annales de Bretagne LXXVII: 95-133.

Fíguls A., Weller 0. (eds.) 2007. Trobada International d'Arqueologia envers l'explotació de la sal a la Prehistória $i$ Protohistória. Acts of the $1^{\text {st }}$ International Archaeology meeting about Prehistoric and Protohistoric salt exploitation, Cardona, 6-8 dec. 2003. Institut de Recerques envers la Cultura. Cardona.

Fíguls A., Weller 0., Grandia F., Bonache J., González J. and Lanaspa R. 2013. La primera explotación minera de la sal gema: la Vall Salina de Cardona (Cataluña, España). Chungara. Revista de Antropología Chilena 45(1): 177195.

Gouletquer P., Kleinmann D. and Weller 0. 1994. Sels et techniques. In M.-Y. Daire (ed.), Le sel gaulois. Dossiers de Centre de Recherche Archéologique d'Alet Q, SaintMalo: 123-161.

Gouletquer P., Weller 0. 2002. Y a-t-il eu des salines au Néolithique en Bretagne? In F. Péron (ed.), Patrimoine Maritime sur les façades maritimes de l'Union Européenne. Actes du colloque international CNRS-UBO-IEUM, Brest, 2000. Presses Universitaires de Rennes. Rennes: 449-453.

Gouletquer P., Weller 0. 2015. Techniques of salt making: from China (Yangtze River) to their world context. In R. Brigand, 0. Weller (eds.), Archaeology of Salt. Approaching an invisible past. Sidestone. Leiden: 13-27.

Harding A. 2013. Salt in Prehistoric Europe. Sidestone Press. Leiden.

Hocquet J.-C., Malpica Cuello A. and Weller 0. 2001. Hommes et paysages du sel. Actes Sud. Paris. 
Jodłowski A. 1977. Die Salzgewinnung auf polnischem Boden in vorgeschichtlicher Zeit und im frühen Mittelalter. Jahreschrift für mitteldeutsche Vorgeschichte 61: 85-103.

Liot C. 2000. Les salines préhispaniques du bassin de Sayula (Occident du Mexique). Milieu et Techniques. British Archaeological Reports IS 849. Monographs in American Archaeology 6. Archaeopress. Oxford.

Monah D., Dumitroaia G., Weller O. and Chapman J. (eds.) 2007. L'exploitation du sel à travers le temps. Actes du colloque international, Piatra Neamt, Roumanie, oct. 2004. Bibliotheca Memoria Antiquitatis XVIII. C. Matasa. Piatra Neamt.

Morin D., Lavier C., Guiomar M. and Fontugne M. 2008. Aux origines de l'extraction du sel en Europe (VIe millénaire av. J-C). La source salée de Moriez, Alpes de Haute Provence. In 0. Weller, A. Dufraisse and P. Pétrequin (eds.), Sel, eau et forêt. D'hier à aujourd'hui. Cahiers de la MSH Ledoux 12 (coll. Homme et environnement 1). Presses Universitaires de Franche-Comté. Besançon: 281-297.

Nikolov V. (ed.) 2008. Provadia-Solnitsata Prehistoric Salt-Producing Center. The 2005-2007 Excavation Seasons. National Institute of Archaeology and Museum. Bulgarian Academy of Sciences. Sofia.

Nikolov V., Bacvarov K. (eds.) 2012. Salt and Gold: The Role of Salt in Prehistoric Europe. Acts of international colloquium Humboldt-Kolleg, oct. 2010. Provadia-Veliko Tarnovo. Verlag Faber. Veliko Tarnovo.

Pétrequin P., Weller 0., Gauthier E. and Dufraisse A. 2001. Salt springs exploitations without pottery during Prehistory. From New Guinea to the French Jura. In S. Beyries, P. Pétrequin (eds.), Ethno-Archaeology and its Transfers. British Aracheological Reports IS 983. Archaeopress. Oxford: 37-65.

Pétrequin P., Weller 0. 2008. L'exploitation préhistorique des sources salées dans le Jura français. Application et critiques d'un modèle prédictif. In 0 . Weller, A. Dufraisse and P. Pétrequin (eds.), Sel, eau et forêt. D'hier à aujourd'hui. Cahiers de la MSH Ledoux 12 (coll. Homme et environnement 1). Presses Universitaires de FrancheComté. Besançon: 255-279.

Weller 0. (ed.) 2002. Archéologie du sel. Techniques et sociétés dans la Pré et Protohistoire européenne. Internationale Archäologie, Arbeitsgemeinschaft Symposium Tagung Kongress 3. Verlag Marie Leidorf GmbH. Rahden. 2002a. Aux origines de l'exploitation du sel en Europe. Vestiges, fonctions et enjeux archéologiques. In 0 . Weller (ed.), Archéologie du sel. Techniques et sociétés. Internationale Archäologie, Arbeitsgemeinschaft Symposium Tagung Kongress 3. Verlag Marie Leidorf $\mathrm{GmbH}$. Rahden: 163-175.

2002b. The earliest rock salt exploitation in Europe. A salt moutain in Spanish Neolithic. Antiquity 76(1): 317-18.

2012. La production chalcolithique du sel à ProvadiaSolnitsata: de la technologie céramique aux implications socio-économiques. In V. Nikolov, K. Bacvarov (eds.), Salt and Gold: The Role of Salt in Prehistoric Europe. Provadia-Veliko Tarnovo. Verlag Faber. Veliko Tarnovo: 67-87.

Weller 0., Ard V. (forthcoming). Prehistoric salt production: technological approach in ceramic studies. European Journal of Archaeology.

Weller O., Dufraisse A. and Pétrequin P. (eds.) 2008. Sel, eau et forêt. D'hier à aujourd'hui. Cahiers de la MSH Ledoux 12 (coll. Homme et environnement 1). Presses Universitaires de Franche-Comté. Besançon.

Weller 0., Dumitroaia G. 2005. The earliest salt production in the world: an early Neolithic exploitation in Poiana Slatinei-Lunca, Romania. Antiquity 79(306). http://anti quity.ac.uk/projgall/weller306/

Weller O., Dumitroaia G., Sordoillet D., Dufraisse A., Gauthier E. and Munteanu R. 2008. Première exploitation de sel en Europe: Techniques et gestion de l'exploitation de la source salée de Poiana Slatinei à Lunca (Neamt, Roumanie). In O. Weller, A. Dufraisse and P. Pétrequin (eds.), Sel, eau et forêt. D'hier à aujourd'hui. Cahiers de la MSH Ledoux 12 (coll. Homme et environnement 1). Presses Universitaires de Franche-Comté. Besançon: 205-230.

Weller 0., Fíguls A. 2013. Die erste Steinsalzgewinnung Europas und der Tauschhandel als wirtschaftlicher Dynamisierer der Mittleren Jungsteinzeit in Katalonien. Das Vall Salina von Cardona (Katalonien, Spanien). Archäologisches Korrespondenzblatt 43(2): 159-173.

Weller O., Pétrequin P., Pétrequin A.-M. and Couturaud A. 1996. Du sel pour les échanges sociaux. L'exploitation des sources salées en Irian Jaya (Nouvelle-Guinée, Indonésie). Journal de la Société des Océanistes 102(1): 3-30. 